\title{
Working Capital Management and Corporate Performance: Evidence from Indonesia
}

\author{
Hadri Kusuma ${ }^{1}$ Ahmad Dhiyaullatief Bachtiar²
}

Submitted: 6.10.17. Final acceptance: 20.02.18

\section{Abstract}

Purpose: The purpose of this paper is to examine the relationship between working capital management and firm performance for firms listed on the Indonesian Stock Exchange. Prior works have employed many indicators of the working capital. The results of previous studies, however, have been inconsistent. This study is an attempt to find out the best proxy of working capital in explaining firm's performance.

Methodology: This study employs regression panels for five measures of working capital to model the data for fifty-four firm-year observations that meet the sampling criteria, covering the time 2010-2014. This study also uses adjusted R-squared as the criteria to select the strongest relationship between measures of working capital and firm performance.

Findings: The findings indicate that all proxies of working capital management met expected signs and statistical significance. Hence, working capital management significantly improves firms' performance. The proxy of inventory turnovers is the best measure of working capital in explaining firm performance.

Originality: To the author's knowledge, this is the first study examining the relationship between five measures of working capital management and firm performance in Indonesia or in any emerging markets; hence, this study contributes to the scarce literature on the management of working capital.

Keywords: working capital, profitability, firm's performance

JEL: G31, M41

\footnotetext{
1 Islamic University of Indonesia

Correspondence address: Islamic University of Indonesia, Jalan Kaliurang Km. 14,5, Yogyakarta, Kabupaten Sleman, Daerah Istimewa Yogyakarta 55584, Indonesia, e-mail: 883120104@uii.ac.id

2 Islamic University of Indonesia

Correspondence address: Islamic University of Indonesia Jalan Kaliurang Km. 14,5, Yogyakarta, Kabupaten Sleman, Daerah Istimewa Yogyakarta 55584, Indonesia, email: ade.bodem.bodem@gmail.com
} 


\section{Introduction}

Studies on the drivers of firm performance are widespread. For example, they show that intellectual capital (Verduijn, 2013), organizational learning (Khosla, 2015), and corporate governance (Herdjiono and Mega Sari, 2017; Kusuma and Ayumardani, 2016) significantly improved firms' performance. However, the notion that working capital management has a relationship to firms' performance has recently received considerable attention. Lean working capital management is one of the most important aspects in financial management of firms. Lean working capital management can be defined as the practice of applying best practices to ensure that the company prevents revenue leakage, increases velocity and reduces costs. Management of working capital generally means managing cash flow, reducing bad debts, and decreasing costs that result in opportunities to maximize firms' value and growth of the company (Cotis, 2004). The more working capital the companies own, the less risk the companies will face. However, too much working capital might not be suitable for companies because they cannot sacrifice profit for long-term development (Jingmeng, 2013). Enough working capital ensures that the companies can continue their operations and satisfy the needs of debenture payments and operational expenses (Arabahmadi and Arabahmadi, 2013). Therefore, working management is vital especially for manufacturing firms, in which the major part of assets is composed of current assets (Deloof, 2003).

Considering the importance of working capital management, the researchers who analyzed the relationship between working capital management and firm performance were inconsistent. For example, Mehta (2014), Akbar (2014), Makori and Jagongo (2013), and Shubita (2013) indicate that the relationship between the cash conversion cycle and profitability of firms was significant, but it is insignificant according to Manzoor (2013). Similarly, Agha et al. (2014), Rehman and Anjum (2013), Gul et al. (2013), and Makarani and Bineshian (2013) find that inventory turnover significantly improved firms' performance, but the relationship is insignificant according to Arshad and Gondal (2013). Previous studies also show contrary results. For example, the relationship between the average payment period and firm performance is negative and insignificant by Makarani and Bineshian (2013) and Manzoor (2013), but Agha et al. (2014), Gul et al. (2013), and Makori and Jagongo (2013) present a positive and significant relationship. Similarly, Rehman and Anjum (2013) find a negative relationship between the current ratio and profitability, but Arshad and Gondal (2013), Arunkumar and Ramanan (2013), and Makori and Jagongo (2013) argue for a positive and significant relationship. These inconsistent and contrary results may stem from different measurements of the working capital and, hence, uphold the ambiguity regarding the appropriate gauges that might serve as the measure of working capital management. 
Therefore, we should find the most important proxy that has the strongest relationship to firm performance.

The objective of this study is to analyze the relationship between working capital management and firm performance. However, this study differs from previous studies in foreign countries. First, this study seeks the most important proxy for working capital. So far, there is no empirical evidence that compares different measures of working capital. Moreover, there are few specific research studies exclusively on the relationship between working capital management and firm performance in manufacturing companies, especially for the case of Indonesia. Nevertheless, scholars recognize that manufacturing sectors strongly contribute to the economy of developing countries. Lastly, while previous studies focused on a certain measure of working capital, this study employs and compares five measures of working capital: cash conversion cycle, inventory turnover ratio, average payment period, current ratio, and net working capital turnover. Therefore, this study provides more comprehensive results than prior works.

Section 2 describes and explains the literature review. Section 3 presents the methodology of the study: its study sample, the operational definition of the study variables, and study models. Section 4 reports the empirical results and, finally, section 5 presents conclusions and recommendation.

\section{Literature Review}

Working capital refers firms' total investment in current assets or assets expected in one year or less. There are two main concepts of working capital: gross working capital and net working capital. The gross working capital is defined as working capital, and it includes the total current assets of the firms. Net working capital is the value difference between the current assets and current liabilities of trade and financial nature (Horne and Wachowicz, 2009). When a firm decides on its current assets and liabilities, we may call it working capital management. Hence, the management of working capital is an accounting approach that emphasizes the mainteinance of proper levels in current assets and liabilities. A firm with good working capital management provides enough cash to meet its short-term obligations (Tufail, 2013).

The research of working capital management is a serious and challenging area. There have been many studies of working capital management and its relationship to firms' 
profitability in many countries. For example, Shin and Soenen (1998) find a strong negative relation between the cash conversion cycle and corporate profitability for a large sample of listed American firms for the 1975-1994 period. However, Abuzayed (2012) argues that profitability positively the cash conversion cycle for firms listed on the small emerging market of Jordan. Moreover, Deloof (2003) presents a significantly negative relation between the gross operating income, the number of accounts receivable, and inventory in Belgium. With similar variables to Deloof's (2003), Teruel and Solano (2007) find a significant negative relation between firms' profitability, the number of accounts receivable, and inventory in Spain. Falope and Ajilore (2009) support the argument of Deloof (2003) about the relationship between the cycle time of accounts payable and profitability in Nigerian firms.

A review of prior studies also indicates that scholars have employed many proxies to measure working capital management. These proxies comprise cash conversion cycle, inventory turnover, average payment period, current ratio, and net working capital ratio, but provide inconsistent results. Mehta (2014), Akbar (2014), and Makori and Jagongo (2013) show that cash conversion cycle significantly impacts profitability, but the relationship is insignificant for Manzoor (2013). Similarly, the relationship between inventory turnover ratio and profitability is significant for Agha et al. (2014), Rehman and Anjum (2013), Gul et al. (2013), and Makarani and Bineshian (2013), but insignificant for Arshad and Gondal (2013). Moreover, the relationship between average payment period and firm profitability is significant for Gul et al. (2013) and Shubita (2013), but insignificant for Manzoor (2013). Furthermore, the relationship between current ratio and profitability is significant for Arshad and Gondal (2013) and Rehman and Anjum (2013), but insignificant for Agha et al. (2014). Lastly, the net working capital turnover ratio is significant according to Rehman and Anjum (2013) and Wuryani (2015), but insignificant for Arshad and Gondal (2013). These inconsistencies raise questions and motivate further study to validate the previous results by difference measures of working capital. This study compares these five measures of working capital and reveals the proxy that shows the strongest result in the relationship between working capital management and firm performance.

\section{Research Method}

The target population of the study conveyed manufacturing companies listed in the LQ45 index of Indonesian Stock Exchange. The sample included companies that met the following criteria: 
a. Consecutive presence in the August and January 2010-2014 index;

b. Publishing of audited annual financial reports;

c. Available data for the studied variables.

Fifty-four firm-year observations met the above criteria, which the author extracted from the official website of Indonesian Stock Exchange (www.idx.co.id). Moreover, the current study employed five measures of working capital management and three controlling variables. These measures show the inconsistency and contrariness of results from previous studies. Table 1 shows the measurement reference for each of the gauges used in this study.

\section{Table 1. Research Variables and their Measurements}

\begin{tabular}{|c|c|c|c|}
\hline No. & Gauges & Measurement & Reference \\
\hline 1 & $\begin{array}{l}\text { Cash Conversion Cycle } \\
\text { (CCC) }\end{array}$ & $\begin{array}{l}\mathrm{CCC}=\text { days of inventory } \\
\text { outstanding (DIO)+days } \\
\text { of sales outstanding (DSO) } \\
\text { - days payable outstanding (DPO) }\end{array}$ & Shin and Soenen (1998) \\
\hline 2 & $\begin{array}{l}\text { Inventory Turnover Ratio } \\
\text { (ITO) }\end{array}$ & $\mathrm{ITO}=$ Sales/Inventory & Agha et al. (2014) \\
\hline 3 & $\begin{array}{l}\text { Average Payment Period } \\
\text { (APP) }\end{array}$ & $\begin{array}{l}\mathrm{APP}=(\text { DaysxPayables }) / \\
\text { Purchases }\end{array}$ & Gul et al. (2013) \\
\hline 4 & Current Ratio (CR) & $\begin{array}{l}\mathrm{CR}=\text { Current Liabilities/Current } \\
\text { Asset }\end{array}$ & Agha et al. (2014) \\
\hline 5 & $\begin{array}{l}\text { Net Working Capital } \\
\text { Turnover Ratio (WCT) }\end{array}$ & $\begin{array}{l}\text { WCT }=\text { Net Sales/( Current } \\
\text { Assets - Current Liabilities) }\end{array}$ & Rehman and Anjum (2013) \\
\hline 6 & $\begin{array}{l}\text { Average Collection Period } \\
(A C P)\end{array}$ & $\begin{array}{l}\text { ACP }=(\text { Days } \times \text { Receivables }) / \\
\text { Sales }\end{array}$ & Akbar (2014) \\
\hline 7 & $\begin{array}{l}\text { Leverage/Debt Ratio } \\
\text { (DTAR) }\end{array}$ & $\begin{array}{l}\text { DTAR = Total Liabilities/Total } \\
\text { Asset }\end{array}$ & $\begin{array}{l}\text { Makoriand Jagongo (2013) } \\
\text { Shubita (2013) }\end{array}$ \\
\hline 8 & Size of Sales (SIZE) & SIZE $=$ LN (Sales) & $\begin{array}{l}\text { Mehta (2014), Makarani } \\
\text { and Bineshian (2013) }\end{array}$ \\
\hline 9 & Return on Assets (ROA) & ROA = Net Income/Total Asset & Teruel and Solano (2007) \\
\hline
\end{tabular}

Source: own elaboration.

Data used in this research is classified as panel data, which is the combination of time series and cross sectional data. The author modeled the relationships between working capital management and firm's profitability by using the equations 3.1-3.5. 


$$
\begin{aligned}
& \mathrm{ROA}_{\text {it }}=\beta_{01}+\beta_{11} \mathrm{ACP}_{\text {it }}+\beta_{21} \mathrm{DTAR}_{\text {it }}+\beta_{31} \mathrm{SIZE}_{\text {it }}+\beta_{41} \mathrm{CCC}_{\text {it }}+\varepsilon_{1 \mathrm{it}} \\
& \mathrm{ROA}_{\text {it }}=\beta_{02}+\beta_{12} \mathrm{ACP}_{\mathrm{it}}+\beta_{22} \mathrm{DTAR}_{\text {it }}+\beta_{32} \mathrm{SIZE}_{\text {it }}+\beta_{42} \mathrm{ITO}_{\text {it }}+\varepsilon_{2 \mathrm{it}} \\
& \mathrm{ROA}_{\text {it }}=\beta_{03}+\beta_{13} \mathrm{ACP}_{\text {it }}+\beta_{23} \mathrm{DTAR}_{\text {it }}+\beta_{33} \mathrm{SIZE}_{\text {it }}+\beta_{43} \mathrm{APP}_{\text {it }}+\varepsilon_{3 \mathrm{it}} \\
& \mathrm{ROA}_{\text {it }}=\beta_{04}+\beta_{14} \mathrm{ACP}_{\text {it }}+\beta_{24} \mathrm{DTAR}_{\text {it }}+\beta_{34} \mathrm{SIZE}_{\text {it }}+\beta_{44} \mathrm{CR}_{\text {it }}+\varepsilon_{4 \mathrm{it}} \\
& \text { ROA }_{\text {it }}=\beta_{05}+\beta_{15} \text { ACP }_{\text {it }}+\beta_{25} \text { DTAR }_{\text {it }}+\beta_{35} \text { SIZE }_{\text {it }}+\beta_{45} \text { WCT }_{\text {it }}+\varepsilon_{5 i t}
\end{aligned}
$$

In which:

$$
\begin{aligned}
& \mathrm{i}=\text { firms } \\
& \mathrm{t}=\text { year } \\
& \varepsilon_{\text {it }}=\text { error term of the model } \\
& \beta_{01-05}=\text { interception of equation } \\
& \beta_{4-35}=\text { coefficients } \\
& \text { DTAR = Debt Ratio / Leverage } \\
& \text { CR = Current Ratio } \\
& \text { SIZE = Size of Sales } \\
& \text { CCC = Cash Conversion Cycle } \\
& \text { ITO = Inventory Turnover Ratio } \\
& \text { APP = Average Payment Period } \\
& \text { WCT = Net Working Capital Turnover } \\
& \text { ACP = Average Collection Period }
\end{aligned}
$$

\section{Data Analysis and Discussions}

This section analyzes and interprets the data with statistical tools. Table 2 presents the summary statistics of the variables used in the present study for fifty-four firmyear observations. The mean value of return on assets is $15.30 \%$ with standard deviation of $11.72 \%$. The mean cash conversion cycle is 19.79 days. On average, firms convert their inventories into sales 6.48 times with a standard deviation of 3.00. The table also shows that the firms averagely take 96.56 days to pay its creditors with a standard deviation of 328.84 days. The typical firm in the sample holds current asset ratio of 2.32 times. The mean accounts collection period is 32.13 days with the standard deviation of 12.51 days. Moreover, the firms have averagely seen their working capital turnover by almost 11.72 times annually. The table also shows that the average firm has the size of 16.73 as measured by the natural logarithm of its total assets. The mean leverage ratio is $43.96 \%$ lagged by total assets. 
Table 2. Descriptive Data

\begin{tabular}{|l|r|r|r|r|}
\hline Variables & Minimum & Maximum & Mean & Std. Deviation \\
\hline CCC & -2332.90 & 267.61 & 19.7956 & 341.18574 \\
\hline ITO & 1.32 & 12.32 & 6.4815 & 3.00814 \\
\hline APP & 0.79 & 2409.84 & 96.5561 & 328.83935 \\
\hline CR & 0.64 & 6.99 & 2.3209 & 1.46898 \\
\hline WCT & -30.07 & 398.96 & 11.7328 & 55.25027 \\
\hline ACP & 0.62 & 57.36 & 32.1309 & 12.50633 \\
\hline DTR & 0.13 & 0.74 & 0.4396 & 0.18464 \\
\hline SIZE & 13.30 & 19.08 & 16.7339 & 1.27656 \\
\hline ROA & -4.64 & 43.42 & 15.3004 & 11.72266 \\
\hline
\end{tabular}

Source: own elaboration.

Table 3 shows that the ROA is negatively related to CCC, APP, and CR. The negative relationship between ROA and CCC indicates that the time lag between of purchases of raw materials and the collection of sales of finished goods can be too long and that decreasing this time lag increases profitability (Deloof, 2003). The negative relation between ROA and APP is consistent with the view that the more the time the customers take to pay their bills, the less cash there is to replenish the inventory, which leads to fewer sales and eventually decreases profitability. Similarly, the negative relation between ROA and APP shows that lagging payments to suppliers makes firms have less cash to purchase inventory for sale, which lowers sales levels and profits. Table 3 also shows that the ROA positively relates to ITO and WCT. The positive relationship indicates that the companies with high turnover in inventory and working capital improve the available cash to buy more inventory and, thus, their sales and profit.

The goal of this study is to test the relationship between working capital management (WCM) and firm's performance. The author measures WCM with the five proxies: cash conversion cycle, inventory turnover, average payment period, current ratio, and net working capital. Return on Asset (ROA) indicates firm performance. To test the relationship this study uses multilinear regression with one independent variable in each of the five measurements and three control variables. Table 4 shows the coefficients of the proxies of working capital management represented by equation 3.1 to 3.5. Table 4 presents that the data support a strong and significant relationship between working capital 
management and firms' performance. All signs of regression coefficients (model 3.1 to 3.5) appear as expected and significant. This result suggests that working capital management improved firm's performance. Below, the author explains each proxy of working capital management.

Table 3. Correlation Matrix

\begin{tabular}{|c|c|c|c|c|c|c|c|c|}
\hline & CCC & ITO & APP & CR & WCT & ACP & DTAR & SIZE \\
\hline ITO & -.0950 & & & & & & & \\
\hline APP & .0100 & -.1450 & & & & & & \\
\hline CR & .3720 & -.1960 & .2790 & & & & & \\
\hline WCT & -.4680 & -.1410 & -.0490 & -.307 & & & & \\
\hline ACP & -.0510 & .1480 & .2950 & .128 & -.1540 & & & \\
\hline DTAR & -.4110 & -.5030 & -.0790 & -.218 & .5860 & -.1190 & & \\
\hline SIZE & -.2680 & .1450 & -.5110 & -.397 & -.0450 & -.1280 & .3490 & \\
\hline ROA & -.3520 & .5770 & -.4780 & -.459 & .0710 & -.0160 & -.0380 & .6040 \\
\hline
\end{tabular}

Source: own elaboration.

Table 4. Regression Result

\begin{tabular}{|c|c|c|c|c|c|c|}
\hline \multirow[t]{2}{*}{ Variable } & \multirow{2}{*}{$\begin{array}{l}\text { Exp. } \\
\text { Sign }\end{array}$} & \multicolumn{5}{|c|}{$\begin{array}{l}\text { Coefficients } \\
\text { (Std. Error) }\end{array}$} \\
\hline & & Model 3.1 & Model 3.2 & Model 3.3 & Model 3.4 & Model 3.5 \\
\hline C & & $\begin{array}{c}-7.6601 \\
(2.5594)^{* * *}\end{array}$ & $\begin{array}{c}-10.643 \\
(2.0578)^{* * *}\end{array}$ & $\begin{array}{c}-8.5627 \\
(2.9087)^{* * *}\end{array}$ & $\begin{array}{c}-8.6851 \\
(2.5295)^{* * *}\end{array}$ & $\begin{array}{c}-14.841 \\
(2.3338)^{* * *}\end{array}$ \\
\hline SIZE & & $\begin{array}{c}0.7968 \\
(0.1293)^{* * *}\end{array}$ & $\begin{array}{c}0.6174 \\
(0.1275)^{* * *}\end{array}$ & $\begin{array}{c}0.7167 \\
(0.1582)^{* * *}\end{array}$ & $\begin{array}{c}0.7323 \\
(0.1392)^{* * *}\end{array}$ & $\begin{array}{c}1.0316 \\
(0.1307)^{* * *}\end{array}$ \\
\hline DTAR & & $\begin{array}{c}-3.4389 \\
(0.9476)^{* * *}\end{array}$ & $\begin{array}{c}0.4179 \\
(1.0004)\end{array}$ & $\begin{array}{c}-2.1080 \\
(0.9500)^{* *}\end{array}$ & $\begin{array}{c}-2.5735 \\
(0.9079) * * *\end{array}$ & $\begin{array}{c}-5.0667 \\
(1.1064)^{\star \star \star}\end{array}$ \\
\hline ACP & & $\begin{array}{c}0.0052 \\
(0.2224)\end{array}$ & $\begin{array}{l}-0.0528 \\
(0.2035)\end{array}$ & $\begin{array}{c}0.2154 \\
(0.2444)\end{array}$ & $\begin{array}{c}0.1406 \\
(0.2265)\end{array}$ & $\begin{array}{c}0.2113 \\
(0.2146)\end{array}$ \\
\hline $\mathrm{CCC}$ & - & $\begin{array}{c}-0.4811 \\
(0.1528)^{* * *}\end{array}$ & & & & \\
\hline ITO & + & & $\begin{array}{c}1.4342 \\
(0.3062)^{* \star *}\end{array}$ & & & \\
\hline
\end{tabular}




\begin{tabular}{|c|c|c|c|c|c|c|}
\hline APP & - & & & $\begin{array}{c}-0.2928 \\
(0.1649)^{*}\end{array}$ & & \\
\hline CR & - & & & & $\begin{array}{c}-0.3130 \\
(0.1163)^{\star * *}\end{array}$ & \\
\hline WCT & + & & & & & $\begin{array}{c}0.7489 \\
(0.1959) * * *\end{array}$ \\
\hline $\begin{array}{l}\text { Adj } \\
\text { R-squared }\end{array}$ & & 0.4933 & 0.5792 & 0.4276 & 0.4692 & 0.5307 \\
\hline
\end{tabular}

The coefficient of cash conversion cycle (CCC) is -0.4811 and significant at $1 \%$ level. This result supports previous studies conducted by Gul et al. (2013), Makarani and Bineshian (2013), Makori and Jagongo (2013), and Mehta (2014). The result implies a low CCC and is a good indicator for companies to manage their working capital efficiently and, therefore, improve performance. In this study, the cash conversion cycle represents the number of inventory days plus the number of accounts receivable days deducted by the number of accounts payable days. A shorter CCC is favorable, and it is entirely possible to have a negative CCC. This would indicate that companies manage their working capital so well that it averagely can purchase and sell inventory and collect the resulting receivables before the corresponding payables from the inventory purchase becomes due (Cagle, Campbell and Jones, 2013).

Inventory turnover ratio (ITO) shows the frequency with which a company sells entire inventory during an accounting period, which is a major factor in the success of any business that holds inventory. ITO also displays how well a company manages its inventory levels and how frequently a company replenishes its inventory. A low inventory turnover ratio reveals that a company may overstock or have deficiencies in the product line or marketing effort. The higher inventory turnover ratios positively indicate effective inventory management. Table 4 shows that the coefficient value of ITO variables is 1.4342 and significant at the level of $1 \%$. This result supports previous studies by Agha et al. (2014), Arshad and Gondal (2013), Gul et al. (2013), Makarani and Bineshian (2013), Manzoor (2013), and Shubita (2013). However, this result contradicts the studies by Arunkumar and Ramanan (2013) and Makori and Jagongo (2013) who find negative and significant impacts. Rehman and Anjum (2013) found that ITO had negative and insignificant impacts on firms' performance.

Moreover, this study defines the average payment period (APP) as days' purchase outstanding, which indicates how many days companies averagely take to pay off 
accounts payables during an accounting period. The lower the ratio, the quicker the business pays liabilities. APP also reveals the average payment terms granted to companies by suppliers. The higher the ratio, the better credit terms the company receives from suppliers. From companies' perspective, an increase in APP improves working capital, while a decrease deteriorates working capital. Accordingly, Table 4 shows that the variable of APP has negative as much signs as -0.2928 and is significant at the level of 10\%. This finding contradicts the studies by Agha et al. (2014), Gul et al. (2013), and Makori and Jagongo (2013), who argue for a positive and significant relationship. However, this study supports the findings by Makarani and Bineshian (2013) and Manzoor (2013).

Furthermore, Table 4 presents that the coefficient of current ratio has negative signs of as much as -0.3130 and is significant at the level of $1 \%$. This result agrees with the findings of Rehman and Anjum (2013), who uncover a negative relationship between current ratio and profitability. Current ratio (CR) reveals the companies' ability to meet short-term maturing obligations. This ratio measures the companies' ability to pay the current debt liabilities. The larger the ratio, the more liquid the company. However, the low current ratio indicates the ability of companies to sell and maintain inventory and, therefore, improve profit. Moreover, the low current ratio can be interpreted as much company's assets are used for growing the business. Therefore, the low current ratio will improve firm's performance. The result of this study supports this expectation. This result, however, disagrees and contradicts the findings of Arshad and Gondal (2013), Arunkumar and Ramanan (2013), and Makori and Jagongo (2013), who argued that current ratio positively and significantly impacts profitability.

Lastly, Table 4 shows that the regression coefficient of net working capital has positive and significant value at $1 \%$, implying that working capital management enhances firm's profitability. This result supports a previous study conducted by Wuryani (2015) but contradicts Rehman and Anjum (2013) and Arshad and Gondal (2013) who find an insignificant relationship between working capital turnover and performance. This result also supports the notion that high turnover ratio positively indicates that the company efficiently manages its short-term assets and liabilities to enhance sales. Similarly, low turnover ratio implies that the management relies too much on accounts receivable and inventory assets to support sales. Such situation can easily lead to an excessive amount of bad debts for the company, as well as obsolete inventory. This result, however, shows that net working capital significantly improves firm's performance.

Adjusted R-squared is a statistical measure of how close the data are to the fitted regression line after the measure has been adjusted to the number of predictors in the 
model. The adjusted R-squared compares the explanatory power of regression models that contain different numbers of predictors. R-squared is always between 0 and 1 . Table 4 shows that the highest adjusted R-squared for this study is 0.5792 (model 2) and the lowest is 0.4276 (model 3). This implies that working management that uses inventory turnover as a proxy is the best model, while the proxy of the average payment period is the worst.

Additional results show the impact of control variables on the profitability. This study used three control variables: average collection period (ACP), debt ratio (DR), and size of the company (SIZE). Table 4 shows that the coefficient for ACP is positive but insignificant for all equations. This is contrary to the coefficient of size, which appears positive and significant for all equations. Moreover, the coefficient of debt ratio is significant for four out of five equations. Therefore, only the size of the company and debt ratio control the relationship between working capital management and firm performance.

\section{Conclusions and Recommendations}

This study aimed to examine the relationship between working capital management (WCM) on the performance of companies. The author measured working capital management with five proxies: cash conversion cycle, inventory turnover ratio, average payment period, current ratio, and working capital turnover ratio, while return on asset is a measure of firm performance. After accounting for three control variables, the result indicates that working capital management significantly improves firm' performance. All proxies of working capital management met the expected signs and appeared as statistically significant. Furthermore, working capital management measured by inventory turnover is the best model in explaining firm performance.

The results of this study bring practical implications. First, the rationale for studying the relationship between working capital management and firms' performance may be a determinant that helps investors to invest in manufacturing firms. If working capital affects the quality of firm performance, then financial mangers must monitor the amount of working capital on a daily basis. Moreover, creditors also can benefit from the results of the current study. They can help them justify their decisions whether to supply inventories and raw materials for particular firms or not.

Nevertheless, what may be a limitation of this study is the small number of observations, despite its significant proportion of population. Future research can extend the period of the study and employ a more rigorous statistical approach to examining the 
working capital. The current study was conducted only for Indonesian manufacturing firms. The author suggests future research to encompass a comparison between the working capital of manufacturing firms in Indonesia and such companies in ASEAN countries. Furthermore, the current study examined the comparative measures of working capital management in relation to firms' performance. However, it did not evaluate the effects of the individual components comprising cash, accounts receivable, inventory, and accounts payable. According to Pratap Singh and Kumar (2014), the possible avenue of further research is behavioral finance. Future studies can be extended to document the behavior of corporate managers in their decision-making process in the areas of the individual component of working capital.

\section{References}

Abuzayed, B. (2012). Working capital management and firms' performance in emerging markets: the case of Jordan. International Journal of Managerial Finance, 8(2): 155-179, http://doi.org/10.1108/17439131211216620

Agha, H. (2014). Impact of Working Capital Management on Profitability. European Scientific Journal, 10(1): 374-381.

Akbar, A. (2014). Working Capital Management and Corporate Performance : Evidences from Textile Sector of China. European Academic Research, II(9): 11440-11456.

Arabahmadi, A. and Arabahmadi, F. (2013). The Role of Working Capital Management in Automobile Industry in Iran. International Research Journal of Applied and Basic Sciences, 4(9): 2491-2493.

Arshad, Z. and Gondal, M.Y. (2013). Impact of Working Capital Management on Profitability a Case of the Pakistan Cement Industry. Interdisciplinary Journal Of Contemporary Research In Business, 5(2): 384-390.

Arunkumar, O.N. and Ramanan, T.R. (2013). Working Capital Management and Profitability: A Sensitivity Analysis. International Journal of Research and Development - A Management Review (IJRDMR) the, 2(1): 52-58.

Cagle, C.S., Campbell, S.N., and Jones, K.T. (2013). Analyzing liquidity using the cash conversion, cycle.http://www.journalofaccountancy.com/issues/2013/may/20126764.html

Cotis, L. (2004). Lean Working Capital Management. Accounting and Tax Periodicals, 106(1), 56, https://www.questia.com/magazine/1P3-527034401/lean-working-capital-management

Deloof, M. (2003). Does working capital management affects profitability of Belgian firms? Journal of Business Finance and Accounting, 30(3): 573-587.

Falope, O.I. and Ajilore, O.T. (2009). Working Capital Management and Corporate Profitability: Evidence from Panel Data Analysis of Selected Quoted Companies in Nigeria. Research Journal of Business Management, 3(3): 73-84, http://doi.org/10.3923/rjbm.2009.73.84

Gul, S., Khan, M.B., Rehman, S.U. and Khan, M.T. (2013). Working Capital Management and Performance of SME Sector. European Journal of Business and Management, 5(1): 60-69.

Herdjiono, I. and Mega Sari, I. (2017). The Effect of Corporate Governance on the Performance of a Company. Some Empirical Findings from Indonesia. Journal of Management and Business Administration. Central Europe, 25(1): 33-52, http://doi.org/10.7206/jmba.ce.2450-7814.188

Horne, J.C. Van and Wachowicz, J.M. (2009). Fundamentals of Financial Management (13th ed.). England: Prentice-Hall, Inc. 
Jingmeng, M. (2013). A Study on Working Capital Management System based on Performance. International Journal of Innovation, Management and Technology, 4(1): 100-103, http://doi.org/10.7763/IJIMT.2013.V4.368

Khosla, A. (2015). Impact of Organisational Culture on Organisational Performance. The Journal of Institute of Public Enterprise, 38(1,2): 150-164, http://doi.org/10.7206/mba.ce.2084-3356.159

Kusuma, H. and Ayumardani, A. (2016). the Corporate Governance Efficiency and Islamic Bank Performance : an Indonesian. Polish Journal of Management Studies, 13(1): 111-120, http://doi.org/10.17512/pjms.2016.13.1.11

Makarani, K.F. and Bineshian, Z. (2013). An empirical study on the relationship between working capital management and profitability: A case study of Mehregan Sangesar Company. Management Science Letters, 3(3): 771-776. http://doi.org/10.5267/j.msl.2013.02.013

Makori, D.M. and Jagongo, A. (2013). Working Capital Management and Firm Profitability: Empirical Evidence from Manufacturing and Construction Firms Listed on Nairobi Securities Exchange. Kenya. International Journal of Accounting and Taxation, 1(1): 1-14.

Manzoor, H. (2013). Working capital management and profitability : Evidence from Cement sector of Pakistan, listed on Karachi stock exchange. Journal of Business Administration and Management Sciences Research, 2(10): 177-185.

Mehta, A. (2014). Working Capital Management and Profitability Relationship-Evidences from Emerging Markets of UAE. International Journal of Management Excellence, 2(3): 195-202.

Pratap Singh, H. and Kumar, S. (2014). Working capital management: a literature review and research agenda. Qualitative Research in Financial Markets, 6(2): 173-197, http://doi.org/10.1108/QRFM-04-2013-0010

Rehman, M. U. and Anjum, N. (2013). Determination of the Impact of Working Capital Management on Profitability: An Empirical Study from the Cement Sector in Pakistan. Asian Economic and Financial Review, 3(3): 319.

Shin, H.-H. and Soenen, L. (1998). Efficiency of Working Capital Management and Corporate Profitability. Financial Practice and Education, 8(2): 37.

Shubita, M.F. (2013). Working Capital Management and Profitability : A Case of Industrial Jordanian Companies. International Journal of Business and Social Science, 4(8): 108-115.

Teruel, P.J.G. and Solano, P.M. (2007). Effects of Working Capital Management on SME Profitability. International Journal of Managerial Finance, 3(2): 164-177, http://doi.org/10.2139/ssrn.894865

Tufail, S. (2013). Impact of Working Capital Management on Profitability of Textile Sector in Pakistan. 3rd International Conference on Business Management: 1-29, http://doi.org/10.2139/ssrn.1663354

Verduijn, K. (2013). From Knowledge to Firm Performance: An Empirical analysis of Intellectual Capital Impact in Polish and Dutch Listed Firms. Management and Business Administration. Central Europe, 21(3): 114-138, http://doi.org/10.7206/mba.ce.2084-3356.75

Wuryani, E. (2015). Australian Journal of Basic and Applied Sciences Analysis Working Capital on Company Profitability. Australian Journal of Basic and Applied Sciences, 9(7): 86-88. 